\title{
Heterotrophic nitrogen fixation in oligotrophic tropical marshes: changes after phosphorus addition
}

\author{
Barbora Černá · Eliška Rejmánková • \\ Jenise M. Snyder · Hana Šantrůčková
}

Received: 24 April 2008/Revised: 8 January 2009/Accepted: 14 January 2009/Published online: 13 February 2009

(C) The Author(s) 2009. This article is published with open access at Springerlink.com

\begin{abstract}
In order to determine the impact of nutrient enrichment on phosphorus $(\mathrm{P})$ limited wetlands, we established experimental $\mathrm{P}$ additions in marshes throughout northern Belize. P significantly increased macrophyte primary production, which led to the rapid elimination of cyanobacterial mats. The replacement of cyanobacterial mats by macrophytes constrained autotrophic nitrogen $(\mathrm{N})$ fixation, increased the quantity, and changed the quality of organic matter input to the sediments. We predicted that the activity of sediment heterotrophic $\mathrm{N}$ fixers will be impacted by these alterations in carbon input. We used the acetylene reduction technique to measure potential (glucose amended) nitrogenase activity (NA) in sediments from controls and treatment plots that have been $\mathrm{P}$ enriched for four years and dominated either by Eleocharis cellulosa, or Typha domingensis for two years. NA in P-enriched plots was 2-3 orders of magnitude higher than NA in controls. NA was positively correlated with the soil reactive $\mathrm{P}$, both total organic and microbial
\end{abstract}

Handling editor: Luis Mauricio Bini

B. Černá $\cdot$ H. Šantrǔčková

Faculty of Science, University of South Bohemia, Branišovská 31, České Budějovice 370 05,

Czech Republic

E. Rejmánková $(\bowtie) \cdot$ J. M. Snyder

University of California Davis, One Shields Ave.,

Davis, CA 95616, USA

e-mail: erejmankova@ucdavis.edu carbon, live root biomass, and total phospholipid fatty acids (PLFA) as an indicator of active microbial biomass. It was negatively correlated with the concentration of ammonium-N. Path analysis revealed that the indirect effect of $\mathrm{P}$ on NA through the root biomass was more important than the direct effect of P. NA of the upper sediment layer was consistently higher in Eleocharis than in Typha dominated plots, despite the higher litter input by Typha. We feel that the higher levels of lignin and phenolics occurring in Typha litter, relative to Eleocharis, constrained NA in Typha plots.

Keywords Heterotrophic nitrogen fixation - Typha . Eleocharis · Cyanobacteria · Phosphorus · Salinity

\section{Introduction}

Biological nitrogen $(\mathrm{N})$ fixation contributes "new" $\mathrm{N}$ to the majority of ecosystems, but despite its importance in ecosystem functioning, ecological controls of $\mathrm{N}$ fixation are relatively poorly understood (Vitousek et al., 2002). Research on biological $\mathrm{N}$ fixation and its role in maintaining soil $\mathrm{N}$ fertility in wetland ecosystems has focused on rice fields (Roger \& Ladha, 1992; Roger, 1995) and coastal wetlands such as salt marshes and mangroves (Pelegri \& Twilley, 1998; Bagwell \& Lovell, 2000; Nielsen et al., 2001; Tyler et al., 2003; Moseman, 2007). However, such research is rather limited in freshwater marshes (Bristow, 1973; 
Tjepkema \& Evans, 1976; Inglett et al., 2004; Scott et al., 2005).

Herbaceous wetland ecosystems generally lack symbiosis-involving legumes and thus the most important $\mathrm{N}$ fixers are $\mathrm{N}$-fixing cyanobacteria and sediment heterotrophic bacteria (Howarth et al., 1988a). Cyanobacterial $\mathrm{N}$ fixation has been described for a variety of freshwater and salt marshes, as well as mangroves (Paerl et al., 1994; Rejmánková \& Komárková, 2000; Tyler et al., 2003; Inglett et al., 2004; Steppe \& Paerl, 2005; Scott et al., 2007; Vargas \& Novelo, 2007). The contribution of cyanobacterial $\mathrm{N}$ fixation to the ecosystem $\mathrm{N}$ economy is relatively high, contributing on average 1-10 (and up to 76) $\mathrm{g} \mathrm{N} \mathrm{m}^{-2} \mathrm{y}^{-1}$ (Howarth et al., 1988a).

Heterotrophic $\mathrm{N}$ fixation has been reported to be closely associated with plant roots (Boyle \& Patriquin, 1981; Bergholz et al., 2001; Nielsen et al., 2001; Moseman, 2007), but the complex interaction between plant roots, root exudates, and microorganisms are poorly understood (Coleman, 2008). Most importantly, though, plants are known to provide a source of available carbon to sediment diazotrophs (Dakora \& Drake, 2000; Bürgmann et al., 2005). Heterotrophic $\mathrm{N}$ fixation varies greatly in wetland sediment, and the rates are generally about an order of magnitude lower than in cyanobacterial mats (Howarth et al., 1988a). Although the $\mathrm{N}$ fixed by diazotrophs may not be immediately available for plant uptake, plants may still benefit from the asymbiotic fixation over time, as nitrogen becomes available through organic $\mathrm{N}$ depolymerization and mineralization (Bürgmann et al., 2005).

Across ecosystems, $\mathrm{N}$ fixation is controlled by a variety of abiotic (bottom-up) and biotic (top-down) factors (Vitousek et al., 2002). In wetlands, these factors include light, redox potential, salinity, carbon substrate availability, inorganic $\mathrm{N}$ and $\mathrm{P}$ concentrations, $\mathrm{Fe}$ and Mo, availability and grazers (Capone \& Kiene, 1988; Howarth et al., 1999). In saline environments, bacteria have to cope with ionic stress, which is balanced by intracellular osmoprotective compounds, many of which are sugars (e.g., disaccharide trehalose, Welsh \& Herbert, 1999) or contain $\mathrm{N}$ (amino acids and their derivatives such as glycine betaine, Csonka, 1989; Galinski \& Trüper, 1994). N fixation thus provides an important source of $\mathrm{N}$ in these, often N-limited, environments (Casselman et al., 1981; Whiting \& Morris, 1986).
Ecosystem functioning of tropical herbaceous wetlands is generally poorly known in spite of their ecological significance. Wetlands of our study system in northern Belize are situated in a flat karstic area with a calcareous marl bedrock and range in size from small $<1$ ha marshes to large shallow inland lagoons $\left(>100 \mathrm{~km}^{2}\right)$. Essentially, all of these wetlands are dominated by benthic cyanobacterial mats with scattered macrophytes, mainly Eleocharis spp., and they are strongly phosphorus (P) limited (Rejmánková et al., 1995; Rejmánková, 2001). No N limitation has been detected in any of the reported studies.

Cyanobacterial mats are characterized by high primary production and relatively high rates of $\mathrm{N}$ fixation (Rejmánková \& Komárková, 2000, 2005). Trophic status of some of these wetlands has been changing recently due to increasing input of nutrients from fertilizer runoff from the sugar cane fields and other crops (Johnson \& Rejmánková, 2005).

Using these wetlands as a model system, we have established a field manipulative experiment to obtain a mechanistic explanation for an ecosystem level response to increased nutrient input along a salinity gradient. The central hypothesis was: The macrophyte/microphyte competition following $\mathrm{P}$ addition will constrain cyanobacterial $\mathrm{N}$ fixation, which eventually will lead to $\mathrm{N}$ limitation. We have confirmed that $\mathrm{P}$ addition promotes the growth of macrophytes (Eleocharis spp. and Typha domingensis), which rapidly reduces cyanobacterial mats (Rejmánková \& Houdková, 2006). The competitive replacement of cyanobacterial mats by macrophytes following $\mathrm{P}$ addition limits $\mathrm{N}$ fixation by cyanobacteria and changes the quantity and quality of organic matter input to the sediments. There is a significant difference in the amount and quality of litter produced by the two macrophytes (litter production on average 800 and $1700 \mathrm{~g} \mathrm{~m}^{-2} \mathrm{y}^{-1}$ for Eleocharis and Typha, respectively; Rejmánková et al., 2008). We expect that the activity of sediment microorganisms, and consequently the $\mathrm{N}$ and $\mathrm{P}$ mineralization processes will be strongly impacted by the quality of input of organic carbon through litter and root exudates. We also expect that, due to processing litter with high $\mathrm{C} / \mathrm{N}$ ratio, soil microorganisms will require extra $\mathrm{N}$ to produce new microbial biomass. In situations where the pool of available $\mathrm{N}$ is limited, most of $\mathrm{N}$ will be immobilized by microbes. Whether this will eventually lead to competition between 
plants and microorganisms for $\mathrm{N}$, and lead to plant $\mathrm{N}$ limitation, will depend on the availability of organic matter, and, consequently, heterotrophic $\mathrm{N}$ fixation.

In this study, we report on the differences in the sediment heterotrophic $\mathrm{N}$ fixation among controls and P-enriched plots dominated either by Eleocharis cellulosa or Typha domingensis, and attempt to explain these differences in the context of abiotic and biotic factors. We hypothesize that: (i) elimination of cyanobacterial mats in P-enriched plots shifts the microbial activity from autotrophs to heterotrophs and increases the microbial activity in sediments, mainly in the rhizosphere; (ii) in Typha dominated plots, the large quantity of litter and larger amount of $\mathrm{C}$-rich root exudates will result in higher demand by sediment microorganisms for $\mathrm{N}$ and will lead to higher heterotrophic $\mathrm{N}$ fixation than in Eleocharis dominated plots; (iii) in higher salinity marshes, the microorganisms may need to invest more energy into osmotic regulation than to the enzyme production, which will result in lower heterotrophic $\mathrm{N}$ fixation.

\section{Methods}

Study site

Our study sites are located in lowlands of northern Belize, Central America within a $50-\mathrm{km}$ radius of $18^{\circ} 9^{\prime} 58^{\prime \prime} \mathrm{N}$ and $88^{\circ} 31^{\prime} 28^{\prime \prime} \mathrm{W}$. This part of the Yucatan Peninsula is an uplifted marine platform composed of a 2-3 km thick sequence of cretaceous and Tertiary limestone, dolomite, and gypsum (Weidie, 1985). Marsh hydrology is closely linked to the ground water system, and water levels are controlled primarily by regional precipitation. The majority of wetlands in the study area remain flooded or saturated year round. Most of the coastal plain contains a freshwater lens many meters thick floating on seawater. The porous limestone aquifer allows inland seawater intrusion, and, as a result, the mixing of fresh and marine waters can occur. Furthermore, the "fresh" ground waters are nearly saturated with carbonate and sulfate, derived from the dissolution of platform rocks. The net result of these factors is that there are large differences in ion content (sulfate, bicarbonate, and chloride) and conductivity of inland wetlands, which vary by several orders of magnitude (0.2-7 mS). Sediments in low conductivity marshes are usually formed by peaty clays, while high conductivity marshes have predominantly marly sediments.

Main primary producers in these systems are several species of emergent macrophytes (Eleocharis cellulosa, E. interstincta, Cladium jamaicense, and Typha domingensis) and speciose communities of microphytes represented mostly by cyanobacteria (Rejmánková et al., 2004).

\section{Treatment plot history}

Fifteen marshes of diverse salinities, all dominated by sparse macrophytes (Eleocharis spp.) and cyanobacterial mats, have been studied as a part of a project aimed at the assessment of ecosystem response to nutrient addition along a salinity gradient (Rejmánková et al., 2008). Four $10 \times 10 \mathrm{~m}$ plots were established in each marsh in August 2001; one represented a control, the remaining three received $\mathrm{N}$, $\mathrm{P}$ and N\&P addition in August 2001, August 2002, and March 2005, N was added as ammonium nitrate and $\mathrm{P}$ as triple super phosphate in amounts corresponding to 20 and $10 \mathrm{~g} \mathrm{~m}^{-2} \mathrm{y}^{-1}$, respectively. In March 2003, one individual of Typha domingensis was planted in each plot. In the majority of the controls and $\mathrm{N}$ addition plots, the Typha plant did not survive. In P-enriched plots, however, they have been growing vigorously and outcompeting Eleocharis. In January 2005, the P addition plots in 6 marshes were manipulated to be half-dominated by Eleocharis and half dominated by Typha. Two of these 6 marshes, one from the low and one from the high salinity categories, were selected to measure the impact of $\mathrm{P}$ addition and macrophyte dominance on the heterotrophic $\mathrm{N}$ fixation (Fig. 1).

Soil and water sampling and analyses

Samples were collected from controls, Eleocharis dominated $\mathrm{P}$ addition plots, and Typha dominated $\mathrm{P}$ addition plots in August 2005 (beginning of wet season) and March 2007 (dry season), respectively (Fig. 1). The plots were always flooded and the water depth ranged from 25 to $50 \mathrm{~cm}$. Recently deposited, readily distinguishable plant detritus on the soil surface was gently removed before sampling. Five randomly located sediment samples were collected with a $5.5-\mathrm{cm}$ diameter sharp edge PVC corer to a depth of 


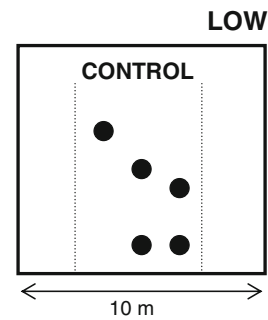

LOW SALINITY

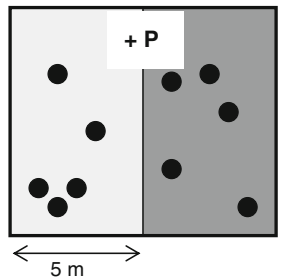

Fig. 1 Schematic of the experimental design and sampling strategy. Five soil cores (black dots) were randomly collected from control plots (white) and P-enriched plots dominated by

approximately $30 \mathrm{~cm}$. Each core was sectioned into the upper (0-7 cm, mostly rhizosphere) and lower (7-30 cm, mostly bulk soil) based on color and texture. Respective layers of all the five cores were combined into a composite sample. Large plant debris, roots, and shells were removed; samples were homogenized and stored on ice until processing. Samples for acetylene reduction assay (ARA) were extracted the same day. Soil samples for the other assays were stored for a maximum of one month at $4^{\circ} \mathrm{C}$, i.e., under the storage conditions recommended when samples could not be analyzed immediately (Alef \& Nannipieri, 2005).

Interstitial water was collected into $\mathrm{HCl}$-rinsed plastic bottles with a suction sampler according to McKee et al. (1988), filtered through a $0.45-\mu \mathrm{m}$ filter and stored on ice until processing. $\mathrm{NH}_{4}-\mathrm{N}$ was determined colorimetrically by the modification of the indolphenol blue method (Liddicoat et al., 1975).

Sediment bulk density was measured for each core section (Singer \& Munns, 1996). Dried soil samples were pretreated with $0.1 \mathrm{M} \mathrm{HCl}$ and analyzed on a Carlo-Erba series $5000 \mathrm{CHN}-\mathrm{S}$ analyzer to obtain the total soil organic carbon and nitrogen. Microbial biomass carbon was determined by fumigation extraction procedures of three 10-g subsamples coupled to a $0.5 \mathrm{M} \mathrm{K}_{2} \mathrm{SO}_{4}$ extraction (White \& Reddy, 2001). The extracted organic $\mathrm{C}$ was determined on a Shimadzu total organic carbon analyzer (TOC-5050A). Microbial biomass C was calculated using the extraction efficiency factor $\mathrm{kEC}=0.37$ as the difference between treated (fumigated) and untreated soils. Biomass nutrient values were expressed per gram soil dry weight. Total $\mathrm{P}$ was analyzed spectrophotometrically using ascorbic acid reduction of phosphomolybdate complex after combustion and consequent acid digestion (McNamara \& Hill, 2000). The soil reactive $\mathrm{P}$ was analyzed using

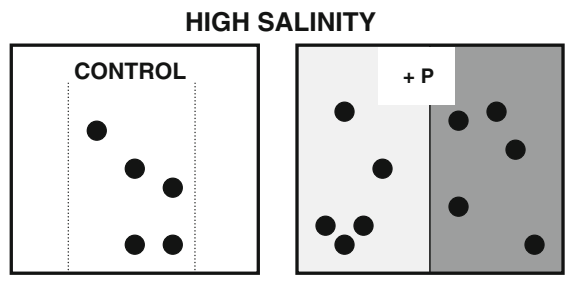

Eleocharis (light gray) and Typha (dark gray). To avoid the discrepancy in plot size of controls; samples were collected in only a $5 \times 10 \mathrm{~m}$ area (indicated by dotted line)

ascorbic acid reduction of phosphomolybdenate complex in oxalate extracts (Owens et al., 1977).

\section{Root stock biomass}

Three additional cores were collected from each plot and sectioned as described above.

All the living and dead plant roots and rhizomes were removed from cores sections by sequentially washing them through a $1-$ and $0.5-\mathrm{mm}$ sieve. The living and dead roots were separated from each sample using a two-phase decanting technique in Ludox TM-50, originally developed for mangrove roots (Robertson \& Dixon, 1993). After separation, roots were oven dried at $80^{\circ} \mathrm{C}$ for $48 \mathrm{~h}$ and weighed for biomass determination.

Acetylene reduction assay (ARA)

We used the ARA method modified from Hardy et al. (1968). Fifty grams of freshly collected water saturated test soil (equal to about $15 \mathrm{~g}$ dry weight) were sealed in 100-ml glass bottles. All the assays were run in triplicates. One $\mathrm{ml}$ of $2 \%$ glucose solution (corresponding to the addition of $0.16 \mathrm{mg} \mathrm{C}$ per $\mathrm{cm}^{3}$ of the sediment) was added to optimize the reaction (Dicker \& Smith, 1980). Glucose is regarded as a good proxy for sucrose, which is likely to originate from wetland macrophyte root exudates (Nielsen et al., 2001). To establish the relationship between the glucose concentration and nitrogenase activity, we set up a separate experiment in which we incubated the samples with glucose concentrations ranging from 0 to $0.42 \mathrm{mg} \mathrm{C} \mathrm{cm}^{-3}$. One set of samples (low salinity marsh, upper sediment layers) was also assayed without the glucose enrichment. The bottles were equilibrated to the atmospheric pressure, $30 \mathrm{ml}$ of the 
headspace were removed and subsequently replaced with $20 \mathrm{ml}$ of $\mathrm{N}_{2}$ gas to lower the partial pressure of oxygen. Ten milliliters of acetylene, freshly prepared from $\mathrm{CaC}_{2}$, were added to each bottle, the bottles were vigorously shaken, and were incubated under dark conditions at $28-30^{\circ} \mathrm{C}$. After 12 and $24 \mathrm{~h}$ the bottles were shaken again, and after $24 \mathrm{~h}$, several milliliters of headspace were withdrawn with an airtight syringe and analyzed by gas chromatograph, using Shimadzu $14 \mathrm{GC}$ with a flame ionization detector and a Porapak$\mathrm{T}$ column at $80^{\circ} \mathrm{C}$. Acetylene-free controls as well as blanks (empty bottles incubated with $10 \mathrm{ml}$ of acetylene) showed no endogenous ethylene production. Gravimetric soil moisture was measured after the incubation. Rates of acetylene reduction were expressed as nmol of acetylene reduced per gram dry mass of sample per day of incubation.

Phopsholipid fatty acid (PLFA) analysis

PLFA analyses were performed according to Frostegård et al. (1993). Phospholipids, in the form of fatty acid methyl esters, were quantified by gas chromatography using Hewlett Packard $6890 \mathrm{~N}$ with FID detector. Since the quantity of microbial PLFA is a function of microbial biomass (Hassett \& Zak, 2005), we used the total amount of all bacterial PLFA identified in the samples as an indicator of live microbial biomass.

Data analysis

We used path analysis, according to Pedhazur (1997), to quantify the relationships among the variables of this study based on a path diagram that specifies the direct and indirect paths between sediment $\mathrm{P}$ and heterotrophic nitrogenase activity.

\section{Results}

All the results are presented for nitrogenase activity (NA) measured in samples enriched with glucose in the amount of $0.16 \mathrm{mg} \mathrm{C} \mathrm{cm}^{-3}$ soil. In the preliminary experiment, NA increased linearly with glucose additions, until about a concentration of $0.3 \mathrm{mg} \mathrm{C}$ $\mathrm{cm}^{-3}$, and further additions had either a null or even negative effect (Fig. 2). NA without glucose was two to three orders of a magnitude lower.

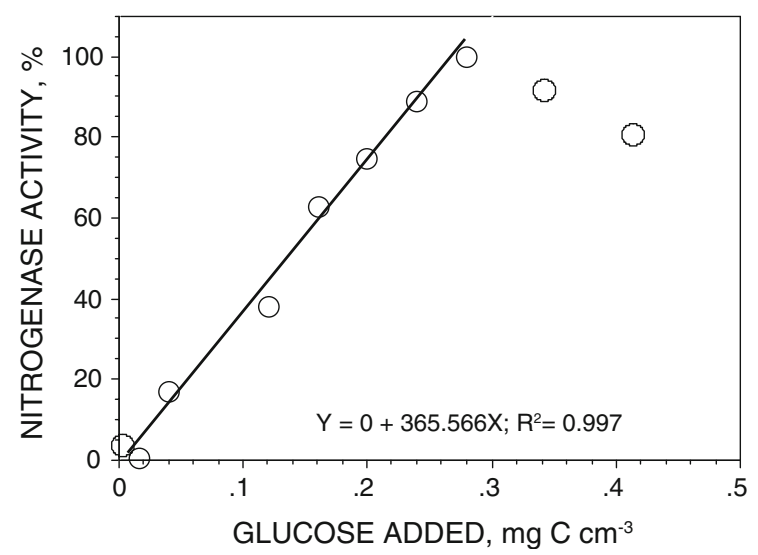

Fig. 2 Mean nitrogenase activity (NA) of composite sediment samples amended with glucose, expressed as $\%$ of the highest value. Each NA assay was run in three replicates

Comparison of nitrogenase activity over all treatments, sediment layers, marsh salinity, and time

We found large differences in NA among control and P-enriched plots in samples from both low- and highsalinity marshes as well as between upper and lower sediment layers (Fig. 3). These patterns were very similar for both sampling periods (August 2005 and March 2007). There was a highly significant difference in NA among treatments and between the sediment layers (Table 1), while the effect of salinity was only marginal. NA in the Typha upper sediment layer was consistently lower, compared to the Eleocharis treatment, while the opposite was true for the lower layers (Fig. 3).

Relationship between nitrogenase activity and environmental variables

To explore how NA relates to changes in chemical and biological sediment variables, we calculated simple regressions (Fig. 4). NA was positively correlated with soil reactive $\mathrm{P}$ (Fig. $4 \mathrm{~A}, R^{2}=0.536, P<0.001$ ), and, albeit less strongly, with total $\mathrm{P}\left(R^{2}=0.44\right.$, $P=0.02$; data not shown). There was a strong negative relationship between NA and $\mathrm{NH}_{4}-\mathrm{N}$ in the interstitial water (Fig. $4 \mathrm{~B}, R^{2}=0.507, P=0.009$ ). NA was also positively correlated with increasing content of total organic carbon, microbial carbon, 


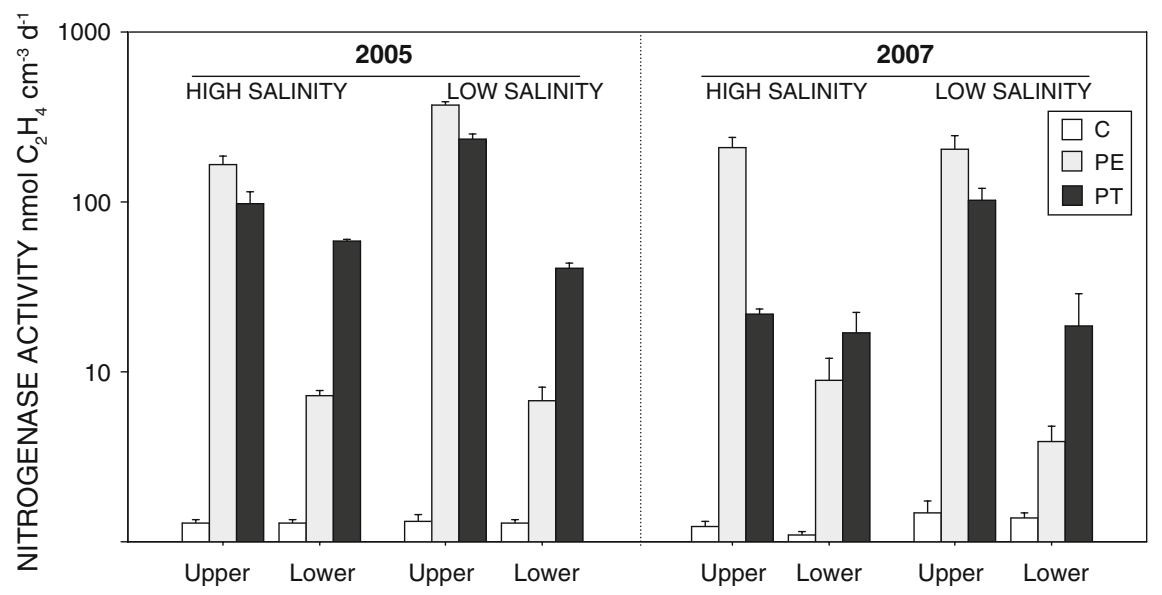

Fig. 3 Nitrogenase activity (NA) measured in August 2005 and March 2007 in the upper and lower layer sediments from controls (C) and $\mathrm{P}$ addition plots dominated by Eleocharis cellulosa (PE) and Typha domingensis (PT). The error bars indicate the standard error of the mean of three replicates, which were taken from a composite sample from each plot. NA is expressed in nmols $\mathrm{C}_{2} \mathrm{H}_{4}$ per $\mathrm{cm}^{3}$ of sediment per day to account for different sediment densities among the upper and lower layers. The log scale was used to better visualize the differences between treatments

Table 1 Mean values $( \pm$ SD) of nitrogenase activity (NA) and sediment characteristics for the upper and lower layer of control and P-enriched sites dominated by Eleocharis or Typha

\begin{tabular}{|c|c|c|c|c|c|c|}
\hline & \multicolumn{3}{|c|}{ High salinity $(7 \mathrm{mS})$} & \multicolumn{3}{|c|}{ Low salinity $(0.2 \mathrm{mS})$} \\
\hline & Control & Eleocharis & Typha & Control & Eleocharis & Typha \\
\hline \multicolumn{7}{|l|}{ Upper layer } \\
\hline $\mathrm{NA}, \mathrm{nmol} \mathrm{C} \mathrm{C}_{2} \mathrm{H}_{4} \mathrm{~g}^{-1} \mathrm{~d}^{-1}$ & $1.18(0.54)$ & $806(52.5)$ & $257(186)$ & $0.92(0.25)$ & $1189(376)$ & $985(475)$ \\
\hline Live root biomass, $\mathrm{mg} \mathrm{g}^{-1}$ & $4.94(0.54)$ & $5.56(0.64)$ & $7.02(1.37)$ & $3.68(1.2)$ & $16.2(1.16)$ & $10.8(0.95)$ \\
\hline Bulk density, $\mathrm{g} \mathrm{cm}^{-3}$ & $0.22(0.01)$ & $0.23(0.04)$ & $0.26(0.04)$ & $0.37(0.05)$ & $0.21(0.02)$ & $0.18(0.03)$ \\
\hline Soil reactive $\mathrm{P}, \mu \mathrm{g} \mathrm{g}^{-1}$ & $0.69(0.07)$ & $6.78(0.49)$ & $6.27(0.02)$ & $0.83(0.09)$ & $8.83(0.31)$ & $16.5(0.25)$ \\
\hline Total soil $\mathrm{P}, \mu \mathrm{g} \mathrm{g}^{-1}$ & 219 & 1175 & 666 & 202 & 367 & 803 \\
\hline $\mathrm{NH}_{4}-\mathrm{N}$ water, $\mu \mathrm{g} 1^{-1}$ & $2486(47.9)$ & $1108(397)$ & $951(75.9)$ & $1252(436)$ & $30.7(13.4)$ & $57.6(20.4)$ \\
\hline Total soil $\mathrm{N}, \mathrm{mg} \mathrm{g}^{-1}$ & $9.3(0.10)$ & $7.5(0.40)$ & $9.1(3.60)$ & $10.6(0.30)$ & $15.0(0.80)$ & $16.9(0.80)$ \\
\hline Microbial $\mathrm{C}, \mu \mathrm{g} \mathrm{g}^{-1}$ & $122(46.1)$ & $154(32.1)$ & $148(16.9)$ & $239(47.5)$ & $409(10.3)$ & $752(3.37)$ \\
\hline Total soil org. $\mathrm{C}, \mathrm{mg} \mathrm{g}^{-1}$ & $98.5(4.50)$ & $165(0.50)$ & $146(2.50)$ & $115(6.00)$ & $187(17.5)$ & $205(16.5)$ \\
\hline Total PLFA, nmolFA $\mathrm{g}^{-1}$ & $248(24.7)$ & $283(30.4)$ & $293(87.9)$ & $145(24.0)$ & $208(33.9)$ & $282(15.1)$ \\
\hline \multicolumn{7}{|l|}{ Lower layer } \\
\hline $\mathrm{NA}, \mathrm{nmol} \mathrm{C}_{2} \mathrm{H}_{4} \mathrm{~g}^{-1} \mathrm{~d}^{-1}$ & $0.60(0.40)$ & $14.0(2.00)$ & $67.0(36.0)$ & $0.78(0.24)$ & $11.5(3.50)$ & $89.0(24.0)$ \\
\hline Live root biomass, $\mathrm{mg} \mathrm{g}^{-1}$ & $0.76(0.03)$ & $1.31(0.11)$ & $1.17(0.22)$ & $0.9(0.07)$ & $1.54(0.15)$ & $3.65(0.35)$ \\
\hline Bulk density, $\mathrm{g} \mathrm{cm}^{-3}$ & $0.49(0.03)$ & $0.52(0.07)$ & $0.56(0.01)$ & $0.50(0.04)$ & $0.40(0.01)$ & $0.35(0.02)$ \\
\hline Soil reactive $\mathrm{P}, \mu \mathrm{g} \mathrm{g}^{-1}$ & $0.38(0.04)$ & $2.00(0.04)$ & $0.16(0.02)$ & $2.65(0.12)$ & $2.59(0.04)$ & $3.72(0.04)$ \\
\hline Total soil $\mathrm{P}, \mu \mathrm{g} \mathrm{g}^{-1}$ & 313 & 189 & 208 & 67 & 105 & 101 \\
\hline Total soil $\mathrm{N}, \mathrm{mg} \mathrm{g}^{-1}$ & $5.80(0.40)$ & $6.60(1.30)$ & $6.30(3.10)$ & $10.4(3.60)$ & $14.2(0.20)$ & $18.7(3.30)$ \\
\hline Microbial $\mathrm{C}, \mu \mathrm{g} \mathrm{g}^{-1}$ & $6.39(2.79)$ & $13.5(1.48)$ & $12.7(0.95)$ & $45.5(12.9)$ & $131(76.4)$ & $77.2(10.1)$ \\
\hline Total soil org. $\mathrm{C}, \mathrm{mg} \mathrm{g}^{-1}$ & $97.5(20.5)$ & $112(4.50)$ & $123(2.50)$ & $60(21.1)$ & $155(18.5)$ & $158(30.0)$ \\
\hline Total PLFA, nmol FA $\mathrm{g}^{-1}$ & $46.7(1.48)$ & $46.4(6.07)$ & $46.2(4.04)$ & $54.5(19.1)$ & $34.7(3.58)$ & $141(18.9)$ \\
\hline
\end{tabular}

The values are averages of 2005 and 2007 sampling dates (each date 3 replicated samples analyzed), except for root biomass that was sampled only in 2007 and total sediment P that was analyzed only in 2005 

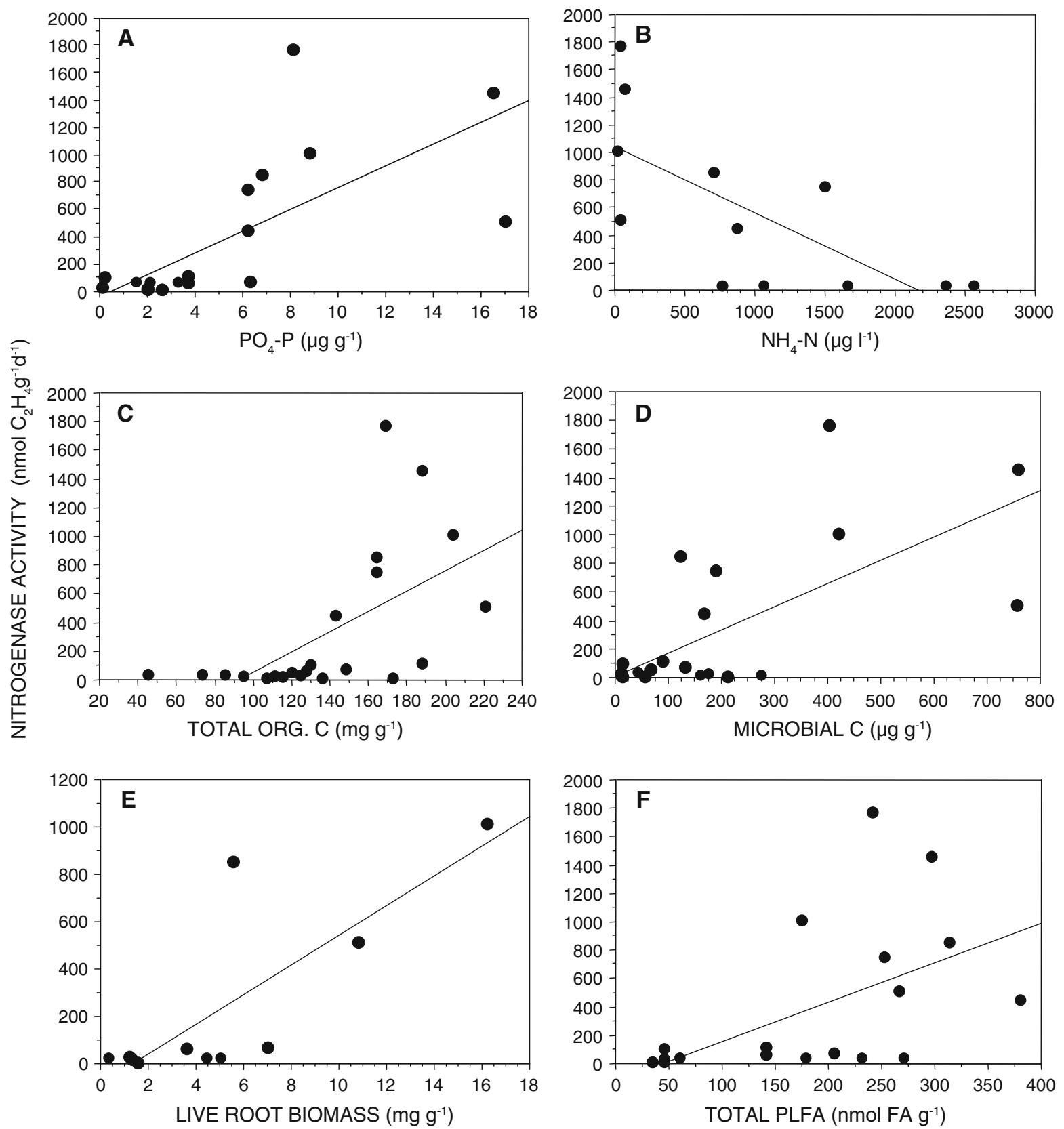

Fig. 4 Relationship between NA and: (A) soil reactive $\mathrm{P}$ $\left(\mathrm{PO}_{4}-\mathrm{P}, \mu \mathrm{g} \mathrm{g}^{-1}\right)$; (B) $\mathrm{NH}_{4}-\mathrm{N}$ in the interstitial water $\left(\mu \mathrm{g} \mathrm{l}^{-1}\right)$; (C) total soil organic carbon $\left(\mathrm{mg} \mathrm{g}^{-1}\right)$; (D) microbial carbon

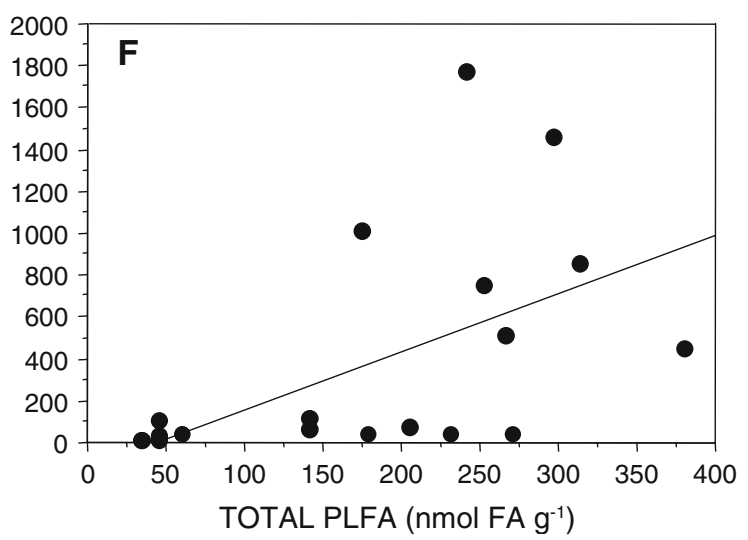

$\left(\mu \mathrm{g} \mathrm{g}^{-1}\right)$ : (E) biomass of live roots (mg dry weight $\mathrm{g}^{-1}$ of sediment); and (F) total PLFA (nmol FA g ${ }^{-1}$ ). Each point represents the mean of three replicates

and total PLFA (Fig. 4C, D and F; $R^{2}=0.369$, $P=0.002 ; R^{2}=0.469, P<0.001 ;$ and $R^{2}=0.353$, $P=0.002$, respectively). We only had data on sediment live root biomass for 2007, but we found a highly significant correlation between sediment live root biomass and NA (Fig. 4E; $R^{2}=0.643$ ).

Path analysis

The effect of sediment $\mathrm{P}$ on NA is clearly very important and it can impact the $\mathrm{N}$ fixing bacteria directly by removing $\mathrm{P}$ deficiency, but also indirectly, through changes in other variables. While NA is 


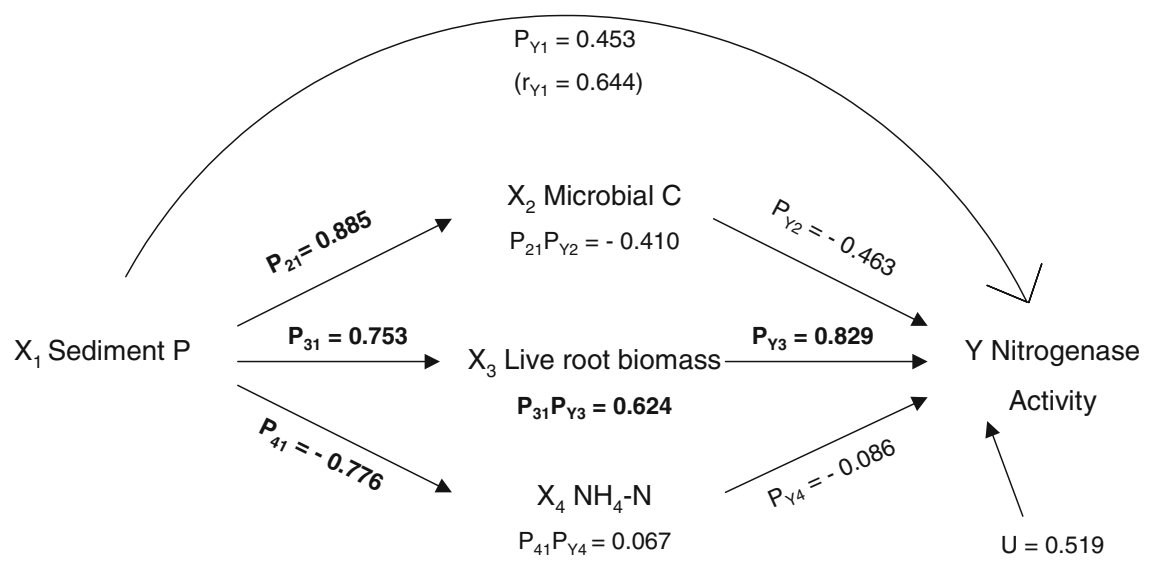

Fig. 5 Path diagram of the direct and indirect effects of sediment phosphorus concentrations on nitrogenase activity (NA). Path coefficients $\mathrm{P}_{21}, \mathrm{P}_{31}$, and $\mathrm{P}_{41}$ are standardized simple regression coefficients, path coefficients $\mathrm{P}_{\mathrm{Y} 1}, \mathrm{P}_{\mathrm{Y} 2}, \mathrm{P}_{\mathrm{Y} 3}$, and $\mathrm{P}_{\mathrm{Y} 4}$ are standardized partial regression coefficients from the multiple regression. Products $\mathrm{P}_{21} \mathrm{P}_{\mathrm{Y} 2}, \mathrm{P}_{31} \mathrm{P}_{\mathrm{Y} 3}$, and $\mathrm{P}_{41} \mathrm{P}_{\mathrm{Y} 4}$ indicate the indirect effects of sediment $\mathrm{P}$ on $\mathrm{NA}$ through microbial carbon, live root biomass, and interstitial water $\mathrm{NH}_{4}^{-}$ $\mathrm{N}$, respectively. Path coefficients printed in bold are significant

positively correlated with total organic $\mathrm{C}$, microbial $\mathrm{C}$, total PLFA, and live root biomass, and negatively correlated with $\mathrm{NH}_{4}-\mathrm{N}$ (Fig. 4), all of these variables have also a significant relationship with sediment $\mathrm{P}$ (see standardized simple regression coefficients $\mathrm{P}_{21}$, $\mathrm{P}_{31}$, and $\mathrm{P}_{41}$ shown in the path analysis, Fig. 5; $\mathrm{P}$ values for all these regressions $<0.05$ ). To elucidate the importance of the indirect effects of $\mathrm{P}$ on NA, we used a simple path analysis (Fig. 5). Because total organic $\mathrm{C}$ and total PLFA did not improve the significance of the multiple regression, only sediment $\mathrm{P}$, microbial $\mathrm{C}, \mathrm{NH}_{4}-\mathrm{N}$, and live root biomass were used in the model. The path analysis revealed that the indirect effect of $\mathrm{P}$ on NA through the root biomass is more important than the direct effect of $\mathrm{P}$ on NA (compare the product of path coefficients $\mathrm{P}_{31}$ $\mathrm{P}_{\mathrm{Y} 3}=0.624$ with $\mathrm{P}_{\mathrm{Y} 1}=0.453$ in Fig. 5).

\section{Discussion}

Response to phosphorus addition

The addition of $\mathrm{P}$ to our experimental plots significantly increased macrophyte primary production, which led to the rapid elimination of both floating and benthic cyanobacterial mats (Rejmánková et al., at $P<0.05$. If both path coefficients forming a product are significant at $P<0.05$, the product is also printed in bold. The residual variable, $U$, includes all the unmeasured variables that affect the dependent variable and its path coefficient $=\sqrt{ } 1-R^{2}$, where $R$ is the proportion of variation in the dependent variable explained by the model. Besides individual path coefficients, the overall correlation between $\mathrm{P}$ sediment and NA are given in parentheses

2008). A similar response has been described for other oligotrophic, P-limited wetlands such as the Florida Everglades (McCormick et al. 1996, 1998; Gaiser et al. 2005). While autotrophic cyanobacteria were eliminated, the biomass of heterotrophic sediment microorganisms increased due to higher $\mathrm{C}$, input, as documented by increase in total organic $\mathrm{C}$ and, consequently, in microbial $\mathrm{C}$, and total PLFA. No significant differences have been found in total $\mathrm{N}$ but the concentration of $\mathrm{NH}_{4}-\mathrm{N}$ in interstitial water, which is typically high in the unimpacted marshes, decreased several fold.

Heterotrophic $\mathrm{N}$ fixation significantly responded to these changes, particularly in the more active upper sediment layers where it was two orders of magnitude higher than in controls. Our first hypothesis stating that the elimination of cyanobacteria in P-enriched plots will shift the microbial activity from autotrophs to heterotrophs and increase the microbial activity in sediments, mainly in the rhizosphere was confirmed.

Heterotrophic $\mathrm{N}$ fixation is strongly dependent on available carbon, where carbon quality is more important for fixation than is quantity (Vitousek et al. 2002). We had two sediment carbon characteristics available: total organic $\mathrm{C}$ and microbial $\mathrm{C}$, and NA was positively associated with both of them. Microbial biomass has also been shown to be closely 
correlated with available C (Sparling et al. 1998; Ghani et al. 2003). However, the variable that was the most tightly correlated with NA was the biomass of live roots, which is in agreement with the fact that diazotrophs are most active and numerous in the environment that is rich in available C, e.g., in the rhizosphere. This "stimulation effect" of root exudates on NA is generally accepted in both terrestrial and wetland ecosystems (Van Berkum \& Sloger, 1979; Welsh et al., 1996; Dakora \& Drake, 2000; Nielsen et al., 2001). Even though our acetylene assays were conducted on sediments from which the roots were previously removed, the rhizosphere microflora was present, and sediment was apparently affected by previous flux of $\mathrm{C}$ from roots. As the root biomass increases in sediment, so also should the area that is enriched by available $\mathrm{C}$. We found significant correlation between live root biomass and available $\mathrm{C}$ in both the upper and lower layers $\left(r^{2}=0.53\right.$ and 0.83 , respectively).

The negative relationship between NA and the concentration of $\mathrm{NH}_{4}-\mathrm{N}$ in the interstitial water was in agreement with the widely accepted claim that the synthesis and/or NA is repressed by high levels of $\mathrm{NH}_{4}-\mathrm{N} / \mathrm{NO}_{3}-\mathrm{N}$ (Yoch \& Whiting, 1986; Howarth et al., 1988b; Hansen et al., 2000).

\section{Plant effects}

We hypothesized that compared to Eleocharis dominated plots, the large quantity of litter and larger amount of C-rich root exudates in Typha-dominated plots would result in higher demand by sediment microorganisms for $\mathrm{N}$ and would lead to higher heterotrophic $\mathrm{N}$ fixation. Results from the upper sediment layer showed a completely opposite trend with consistently higher NA in Eleocharis plots rather than in Typha (Fig. 3). However, in the lower sediment layers, we found higher NA in Typha plots. We believe this discrepancy exists due to differences in stand age. Since Typha became fully established in plots only in 2005, its litter probably only impacts the upper sediment layers. Most importantly though, we found higher phenolic and lignin contents in Typha litter as opposed to Eleocharis litter (phenolics $5.68 \pm 1.5 \%$ and $2.09 \pm 0.7 \%$; lignin: $3.85+0.99 \%$ and $1.52+$ $0.38 \%$ in dry leaf material, respectively; Rejmánková, unpublished data). Both phenolics and lignin have been found to limit N fixation (Pelegri \& Twilley, 1998).
Thus it is conceivable, that the higher levels of these compounds constrained NA in Typha plots relative to Eleocharis.

\section{Salinity effects}

The effects of salinity on NA were not conclusive, and NA was not consistently lower in the high salinity plots. Finding lower NA in some plots from higher salinity marshes could be a result of a smaller, less active community of $\mathrm{N}$ fixers due to salinity stress. We can also speculate that $\mathrm{N}$ fixers in the high salinity plots would need to invest more energy into osmotic regulation than to the enzyme production. There are conflicting reports on the effects of salinity on NA. While some studies have found that concentrations of $\mathrm{NaCl}$ as low as $75 \mathrm{mM}$ can have a negative impact on $\mathrm{NA}$ in symbiotic $\mathrm{N}$ fixers (Bolaňos et al., 2006), others have reported no effects from highly saline environments (Zahran, 1997). The extent by which $\mathrm{N}$ fixers are constrained by salinity in our system will be explored in future research.

In conclusion, our data show that $\mathrm{P}$ addition controls heterotrophic $\mathrm{N}$ fixation mainly via root development, although litter input quality also appears to be important. The estimate of $\mathrm{N}$ balances indicates that microbial $\mathrm{N}$ fixation, under conditions of unlimited carbon supply could potentially cover and even exceed plant $\mathrm{N}$ demand.

Acknowledgments We would like to thank Ireneo Briceno and Russell King for their assistance in the field, Emily Carlson for laboratory assistance, Marcel Rejmánek for comments to the first draft of the article, and to the journal editor and the two anonymous reviewers for their helpful comments and suggestions. This research was supported by these grants: NSF grant \# 0089211 to E. R.; ME 912, and MSM \# 6007665801 to H.S.

Open Access This article is distributed under the terms of the Creative Commons Attribution Noncommercial License which permits any noncommercial use, distribution, and reproduction in any medium, provided the original author(s) and source are credited.

\section{References}

Alef, K. \& P. Nannipieri, 2005. Methods in Applied Soil Microbiology and Biochemistry. Academic Press, London. Bagwell, C. E. \& C. R. Lovell, 2000. Microdiversity of culturable diazotrophs from the rhizoplanes of the salt marsh 
grasses Spartina alterniflora and Juncus roemerianus. Microbial Ecology 39: 128-136.

Bergholz, P. W., C. E. Bagwell \& C. R. Lovell, 2001. Physiological diversity of rhizoplane diazotrophs of the saltmeadow cordgrass, Spartina patens: implications for host specific ecotypes. Microbial Ecology 42: 466-473.

Bolaňos, L., M. Martin, A. El-Hamdaoui, R. Rivilla \& I. Bonilla, 2006. Nitrogenase inhibition in nodules from pea plants grown under salt stress occurs at the physiological level and can be alleviated by B and Ca. Plant and Soil 280: 135-142.

Boyle, C. D. \& D. G. Patriquin, 1981. Carbon metabolism of Spartina-alterniflora loisel in relation to that of associated nitrogen-fixing bacteria. New Phytologist 89: 275-288.

Bristow, J. M., 1973. Nitrogen-fixation in rhizosphere of aquatic angiosperms. Plant Physiology 51: 34.

Bürgmann, H., S. Meier, M. Bunge, F. Widmer \& J. Zeyer, 2005. Effects of model root exudates on structure and activity of a soil diazotroph community. Environmental Microbiology 7: 1711-1724.

Capone, D. G. \& R. P. Kiene, 1988. Comparison of microbial dynamics in marine and fresh-water sediments - contrasts in anaerobic carbon catabolism. Limnology and Oceanography 33: 725-749.

Casselman, M. E., W. H. Patrick \& R. D. Delaune, 1981. Nitrogen-fixation in a gulf-coast salt-marsh. Soil Science Society of America Journal 45: 51-56.

Coleman, D. C., 2008. From peds to paradoxes: linkages between soil biota and their influences on ecological processes, review. Soil Biology and Biochemistry 40: 271-289.

Csonka, L. N., 1989. Physiological and genetic responses of bacteria to osmotic-stress. Microbiological Reviews 53: 121-147.

Dakora, F. D. \& B. G. Drake, 2000. Elevated $\mathrm{CO}_{2}$ stimulates associative $\mathrm{N}_{2}$ fixation in a C-3 plant of the Chesapeake Bay wetland. Plant Cell and Environment 23: 943-953.

Dicker, H. J. \& D. W. Smith, 1980. Acetylene reduction (nitrogen fixation) in a Delaware, USA salt marsh. Marine Biology 57: 241-250.

Frostegård, A., A. Tunlid \& E. Bååth, 1993. Phospholipid fatty-acid composition, biomass, and activity of microbial communities from 2 soil types experimentally exposed to different heavy-metals. Applied and Environmental Microbiology 59: 3605-3617.

Galinski, E. A. \& H. G. Trüper, 1994. Microbial behavior in salt-stressed ecosystems. FEMS Microbiology Reviews 15: 95-108.

Gaiser, E. E., J. C. Trexler, J. H. Richards, D. L. Childers, D. Lee, A. L. Edwards, L. J. Scinto, K. Jayachandran, G. B. Noe \& R. D. Jones, 2005. Cascading ecological effects of low-level phosphorus enrichment in the Florida Everglades. Journal of Environmental Quality 34: 717-723.

Ghani, A., M. Dexter \& K. W. Perrott, 2003. Hot-water extractable carbon in soils: a sensitive measurement for determining impacts of fertilisation, grazing and cultivation. Soil Biology and Biochemistry 35: 1231-1243.

Hansen, J. W., J. W. Udy, C. J. Perry, W. C. Dennison \& B. A. Lomstein, 2000. Effect of the seagrass Zostera capricorni on sediment microbial processes. Marine Ecology-Progress Series 199: 83-96.
Hardy, R. W. F., R. D. Holsten, E. K. Jackson \& R. C. Burns, 1968. Acetylene-ethylene assay for $\mathrm{N}_{2}$ fixation - laboratory and field evaluation. Plant Physiology 43: 1185-1207.

Hassett, J. E. \& D. R. Zak, 2005. Aspen harvest intensity decreases microbial biomass, extracellular enzyme activity, and soil nitrogen cycling. Soil Science Society of America Journal 69: 227-235.

Howarth, R. W., R. Marino, J. Lane \& J. J. Cole, 1988a. Nitrogen-fixation in fresh-water, estuarine, and marine ecosystems. 1. Rates and importance. Limnology and Oceanography 33: 669-687.

Howarth, R. W., R. Marino \& J. J. Cole, 1988b. Nitrogenfixation in fresh-water, estuarine, and marine ecosystems. 2. Biogeochemical controls. Limnology and Oceanography 33: 688-701.

Howarth, R. W., F. Chan \& R. Marino, 1999. Do top-down and bottom-up controls interact to exclude nitrogen-fixing cyanobacteria from the plankton of estuaries? An exploration with a simulation model. Biogeochemistry 46: 203-231.

Inglett, P. W., K. R. Reddy \& P. V. McCormick, 2004. Periphyton chemistry and nitrogenase activity in a northern Everglades ecosystem. Biogeochemistry 67: 213-233.

Johnson, S. \& E. Rejmánková, 2005. Impacts of land use on nutrient distribution and vegetation composition of freshwater wetlands in Northern Belize. Wetlands 25: 89-100.

Liddicoat, M. I., S. Tibbitts \& E. I. Butler, 1975. Determination of ammonia in seawater. Limnology and Oceanography 20: 131-132.

McCormick, P. V., P. S. Rawlik, K. Lurding, E. P. Smith \& F. H. Sklar, 1996. Periphyton-water quality relationships along a nutrient gradient in the northern Florida Everglades. Journal of the North American Benthological Society 15: 433-449.

McCormick, P. V., R. B. E. Shuford, J. G. Backus \& W. C. Kennedy, 1998. Spatial and seasonal patterns of periphyton biomass and productivity in the northern Everglades, Florida, USA. Hydrobiologia 362: 185-208.

McKee, K. L., I. A. Mendelssohn \& M. W. Hester, 1988. Reexamination of pore water sulfide concentrations and redox potentials near the aerial roots of Rhizophora mangle and Avicennia germinans. American Journal of Botany 75: 1352-1359.

McNamara, A. E. \& W. R. Hill, 2000. UV-B irradiance gradient affects photosynthesis and pigments but not food quality of periphyton. Freshwater Biology 43: 649-662.

Moseman, S. M., 2007. Opposite diel patterns of nitrogen fixation associated with salt marsh plant species (Spartina foliosa and Salicornia virginica) in southern California. Marine Ecology-an Evolutionary Perspective 28: 276-287.

Nielsen, L. B., K. Finster, D. T. Welsh, A. Donelly, R. A. Herbert, R. de Wit \& B. A. Lomstein, 2001. Sulphate reduction and nitrogen fixation rates associated with roots, rhizomes and sediments from Zostera noltii and Spartina maritima meadows. Environmental Microbiology 3: 63-71. 
Owens, L. B., D. W. Nelson \& L. E. Sommers, 1977. Determination of inorganic phosphorus in oxalate extracts of soils. Soil Science Society of America Journal 41: 148-149.

Paerl, H. W., B. M. Bebout, C. A. Currin, M. W. Fitzpatrick \& J. L. Pickney, 1994. Nitrogen fixation in microbial mats. In Stal, L. J. \& P. Caumette (eds), Microbial mats. Structure, development and environmental significance. NATO ASI Springer Verlag, Heidelberg: 325-337.

Pedhazur, E. J., 1997. Multiple regression in behavioral research: explanation and prediction. Hartcourt Brace College Publishers, Fort Worth, Texas.

Pelegri, S. P. \& R. R. Twilley, 1998. Heterotrophic nitrogen fixation (acetylene reduction) during leaf-litter decomposition of two mangrove species from south Florida, USA. Marine Biology 131: 53-61.

Rejmánková, E., K. O. Pope, M. D. Pohl \& J. M. Rey Benayas, 1995. Fresh-water wetland plant-communities of Northern Belize - implications for paleoecological studies of Maya wetland agriculture. Biotropica 27: 28-36.

Rejmánková, E. \& J. Komárková, 2000. A function of cyanobacterial mats in phosphorus-limited tropical wetlands. Hydrobiologia 431: 135-153.

Rejmánková, E., 2001. Effect of experimental phosphorus enrichment on oligotrophic tropical marshes in Belize, Central America. Plant and Soil 236: 33-53.

Rejmánková, E., J. Komárek \& J. Komárková, 2004. Cyanobacteria - a neglected component of biodiversity: patterns of species diversity in inland marshes of Northern Belize (Central America). Diversity and Distributions 10: 189-199.

Rejmánková, E. \& J. Komárková, 2005. Response of cyanobacterial mats to nutrient and salinity changes. Aquatic Botany 83: 87-107.

Rejmánková, E. \& K. Houdková, 2006. Wetland plant decomposition under different nutrient conditions: what is more important, litter quality or site quality? Biogeochemistry 80: 245-262.

Rejmánková, E., P. Macek \& K. Epps, 2008. Wetland ecosystem changes after three years of phosphorus addition. Wetlands 28: 914-927.

Robertson, A. I. \& P. Dixon, 1993. Separating live and dead fine roots using colloidal silica - an example from mangrove forests. Plant and Soil 157: 151-154.

Roger, P. A., 1995. Biological N-2-fixation and its management in wetland rice cultivation. Fertilizer Research 42: 261-276.

Roger, P. A. \& J. K. Ladha, 1992. Biological $\mathrm{N}_{2}$ fixation in wetland rice fields - estimation and contribution to nitrogen-balance. Plant and Soil 141: 41-55.

Scott, J. T., R. D. Doyle \& C. T. Filstrup, 2005. Periphyton nutrient limitation and nitrogen fixation potential along a wetland nutrient-depletion gradient. Wetlands 25: 439-448.

Scott, J. T., R. D. Doyle, J. A. Back \& S. I. Dworkin, 2007. The role of $\mathrm{N}_{2}$ fixation in alleviating $\mathrm{N}$ limitation in wetland metaphyton: enzymatic, isotopic, and elemental evidence. Biogeochemistry 84: 207-218.
Singer, M. J. \& D. N. Munns, 1996. Soils. An Introduction, 3rd ed. Prentice-Hall, London: 77-78.

Sparling, G., M. Vojvodic-Vukovic \& L. A. Schipper, 1998. Hot-water-soluble $\mathrm{C}$ as a simple measure of labile soil organic matter: the relationship with microbial biomass $\mathrm{C}$. Soil Biology and Biochemistry 30: 1469-1472.

Steppe, T. F. \& H. W. Paerl, 2005. Nitrogenase activity and Nifh expression in a marine intertidal microbial mat. Microbial Ecology 49: 315-324.

Tjepkema, J. D. \& H. J. Evans, 1976. Nitrogen-fixation associated with Juncus-balticus and other plants of Oregon wetlands. Soil Biology and Biochemistry 8: 505-509.

Tyler, A. C., T. A. Mastronicola \& K. J. McGlathery, 2003. Nitrogen fixation and nitrogen limitation of primary production along a natural marsh chronosequence. Oecologia 136: 431-438.

Van Berkum, P. \& C. Sloger, 1979. Immediate acetylenereduction by excised grass roots not previously pre-incubated at low oxygen-tensions. Plant Physiology 64: 739-743.

Vargas, R. \& E. Novelo, 2007. Seasonal changes in periphyton nitrogen fixation in a protected tropical wetland. Biology and Fertility of Soils 43: 367-372.

Vitousek, P. M., K. Cassman, C. Cleveland, T. Crews, C. B. Field, N. B. Grimm, R. W. Howarth, R. Marino, L. Martinelli, E. B. Rastetter \& J. I. Sprent, 2002. Towards an ecological understanding of biological nitrogen fixation. Biogeochemistry 57: 1-45.

Weidie, A. E., 1985. Geology of the Yucatan platform, part 1. In Ward, W. C., A. E. Weidie \& W. Back (eds), Geology and hydrogeology of the Yucatan and quaternary geology of northeastern Yucatan peninsula. Geological Society, New Orleans, LA: 1-19.

Welsh, D. T. \& R. A. Herbert, 1999. Osmotically induced intracellular trehalose, but not glycine betaine accumulation promotes desiccation tolerance in Escherichia coli. FEMS Microbiology Letters 174: 57-63.

Welsh, D. T., P. Wellsbury, S. Bourgues, R. de Wit \& R. A. Herbert, 1996. Relationship between porewater organic carbon content, sulphate reduction and nitrogen fixation (acetylene reduction) in the rhizosphere of Zostera noltii. Hydrobiologia 329: 175-183.

White, J. R. \& K. R. Reddy, 2001. Influence of selected inorganic electron acceptors on organic nitrogen mineralization in Everglades soils. Soil Science Society of America Journal 65: 941-948.

Whiting, G. J. \& J. T. Morris, 1986. Nitrogen-fixation $\left(\mathrm{C}_{2} \mathrm{H}_{2}\right.$ reduction) in a salt-marsh - its relationship to temperature and an evaluation of an in situ chamber technique. Soil Biology and Biochemistry 18: 515-521.

Yoch, D. C. \& G. J. Whiting, 1986. Evidence for $\mathrm{NH}_{4}{ }^{+}$switchoff regulation of nitrogenase activity by bacteria in saltmarsh sediments and roots of the grass Spartina-alterniflora. Applied and Environmental Microbiology 51: 143-149.

Zahran, H. H., 1997. Diversity, adaptation and activity of the bacterial flora in saline environments. Biology and Fertility of Soils 25: 211-223. 